\title{
Analysing the policy space for the promotion of healthy, sustainable edible oil consumption in India
}

\author{
Soledad Cuevas $1,2, *$, Shauna M Downs ${ }^{3}$, Suparna Ghosh-Jerath ${ }^{4}$, Aafrin ${ }^{4}$ and \\ Bhavani Shankar ${ }^{1,2}$ \\ 'SOAS University of London, Thornhaugh Street, Russell Square, London WC1H OXG, UK: ${ }^{2}$ Leverhulme Centre for \\ Integrative Research on Agriculture and Health, London, UK: ${ }^{3}$ Rutgers School of Public Health, Newark, NJ, USA: \\ ${ }^{4}$ Public Health Foundation of India, Indian Institute of Public Health - Delhi, Gurgaon, India
}

Submitted 7 June 2018: Final revision received 1 April 2019: Accepted 16 April 2019: First published online 6 August 2019

\begin{abstract}
Objective: To identify opportunities and challenges for the promotion of healthy, sustainable oil consumption in India.

Design: We use a framework for policy space analysis which distinguishes between policy context, process and characteristics.

Setting: We focus on the Indian edible oils sector and on factors shaping the policy space at a national level.

Participants: The study is based on the analysis of policy documents and semistructured interviews with key experts and stakeholders in the edible oils sector. Results: We find opportunities associated with the emergence of multisectoral policy frameworks for climate adaptation and non-communicable disease (NCD) prevention at a national level which explicitly include the oils sector, the existence of structures for sectoral policy coordination, some supportive factors for the translation of nutrition evidence into practice, and the possibility of integrating nutrition-sensitive approaches within current state-led agricultural interventions. However, the trade-offs perceived across sustainability, NCD prevention and food security objectives in the vegetable oils sector are considered a barrier for policy influence and implementation. Sustainability and nutrition advocates tend to focus on different segments of the value chain, missing potential synergies. Moreover, policy priorities are dominated by historical concerns for food security, understood as energy provision, as well as economic and strategic priorities.

Conclusions: Systematic efforts towards identifying synergistic approaches, from agricultural production to distribution of edible oils, as well as increased involvement of nutrition advocates with upstream policies in the oils sector, could increase policy influence for advocates of both nutrition and sustainability.
\end{abstract}

India is experiencing a nutrition transition associated with a wider process of trade liberalization, urbanization and demographic change ${ }^{(1,2)}$. This process includes increases in energy consumption from sugar, fat and processed foods and has led to diets lacking in micronutrients ${ }^{(3,4)}$. It contributes to increased burdens of overweight/obesity and noncommunicable disease (NCD), including diabetes and CVD, which coexist with stunting and undernutrition ${ }^{(5)}$. Food policy interventions, therefore, need to balance concerns related to food security and undernutrition as well as overweight/obesity and diet-related $\mathrm{NCD}^{(6)}$.
The transition to a 'Westernized' diet in developing countries is usually accompanied by increased consumption of vegetable edible oils ${ }^{(1)}$. In the case of India, following the liberalization of the edible oils sector in 1994, consumption of imported oils rose rapidly. Consumption of palm oil, which is not used in traditional Indian cooking and is mainly imported, increased from under 500 tonnes in 1994 to almost 10 million tonnes in $2016^{(7)}$, or up to $40 \%$ of total consumption. This makes India the largest importer of palm oil worldwide and the second largest consumer. 
From the nutritional viewpoint, palm oil is an affordable source of energy which, however, is high in saturated fats compared with traditionally consumed oils such as rapeseed/mustard oils ${ }^{(8)}$. This has led to health concerns ${ }^{(9,10)}$ because saturated fats have been linked to increased risk of $\mathrm{CVD}^{(11-13)}$. A recent study has estimated that a tax on palm oil could save over 400000 deaths from myocardial infarction $^{(10)}$.

From a sustainability viewpoint, the dynamics in the Indian palm oil sector can also have important environmental implications in the supplying countries, mainly Malaysia and Indonesia, where palm oil cultivation has been linked to deforestation of tropical forests which are valuable carbon sinks and biodiversity reserves ${ }^{(14)}$. Reduced demand for unsustainable palm oil from the Indian market has been identified as a key step towards mitigating global environmental impacts of palm oil production $^{(15,16)}$. Moreover, domestic production is also vulnerable, with low yield owing to factors like degraded soil, lack of access to good-quality seed, inefficient use of fertilizer and unsustainable irrigation ${ }^{(17-19)}$.

Previous studies have used a value chains approach to identify opportunities and barriers to improve the supply of healthy oils in India ${ }^{(8,17)}$. Most recently, Shankar et al. ${ }^{(20)}$ analysed the opportunities and challenges for policies to promote healthy and sustainable oil consumption in Thailand. In the present study, we analyse the policy space for the promotion of healthy, sustainable oil consumption in the Indian edible oils sector, with a focus on healthy fat consumption, as shaped by the historical, international and political context. Further, the policy processes and the characteristics of key existing policies regulating the oils sector are also explored.

\section{Methods}

\section{Theoretical framework}

To analyse the policy space, we use a framework which situates itself between societal and state-centred approaches and has been used for policy space analysis of the dual burden of malnutrition in India ${ }^{(6,21)}$. Societal approaches assume that policy action is a reflection of social interests or the pressures of interest groups, leaving little room to account for initiative, leadership, training or ideology in policy making ${ }^{(22)}$. State-centred theories, on the contrary, assume that "policy occurs within bureaucratic organizations $^{(21)}$. Policy space analysis bridges the gap between these approaches, providing a useful analytic lens, particularly when it comes to explaining 'good policy'. This framework distinguishes between contextual factors, agenda-setting circumstances or policy processes and the characteristics of specific policy interventions, as outlined in Table 1.

In the present study, we focus on policies directly addressing the edible oils sector or oil and fat consumption
Table 1 Theoretical framework: policy space analysis

\begin{tabular}{ll}
\hline Policy context & Refers to broader historical, \\
international, political or socio- \\
economic factors which are not \\
part of the policy process itself but \\
can shape policy decisions and \\
approaches \\
The circumstances and process \\
under which specific interventions \\
are taken are determined by the \\
roles, priorities, perceptions and \\
influence of different state and \\
non-state actors, including \\
agenda-setting \\
economic interest groups, civil \\
society and experts. Dimensions \\
such as the perceived urgency of \\
the intervention or the status and \\
legitimacy of state agents and \\
other actors with a stake in the \\
policy process are important \\
elements of the analysis \\
Aspects of existing or proposed \\
policies can pose opportunities \\
and barriers for intervention, \\
particularly insofar as they shape \\
perceptions or elicit reactions in \\
the bureaucratic and public \\
arenas. These can include explicit \\
goals and approaches, distribution \\
of costs and impacts, etc. \\
The 'policy space' is shaped by the \\
views and interests of \\
organizations and social groups \\
who have a stake in how a \\
specific system functions (56) as \\
well as by policy makers' \\
perceptions and political legacy \\
Policy characteristics
\end{tabular}

and operating at a sectoral level. These include both state policy and private or multi-stakeholder 'collective' regulatory frameworks ${ }^{(23)}$. An analysis of 'business-to business' policies and standards of individual companies is beyond the study's scope.

\section{Sampling, data collection and analysis}

The present study is based on the analysis of policy documents and semi-structured interviews with experts and stakeholders. The research protocol was approved by the ethical review boards of the London School of Hygiene and Tropical Medicine and the Public Health Foundation of India.

To determine sampling size, we aimed for adequate 'information power' ${ }^{\text {(24) }}$. Guided by our theoretical framework we sought a small but highly informative and specific sample, and to include interviewees representing different interests, perspectives, expertise and viewpoints. In total, fourteen semi-structured interviews each of approximately 40 min duration were carried out in India with key experts and stakeholders from state, civil society, industry and academic sectors. Although the classification of actors is analogous to that used by Lang and Heasman ${ }^{(25)}$, we include as a distinct category academic experts, who play a role in 
Healthy, sustainable oil consumption in India

Table 2 Main policy documents in the Indian edible oils sector

\begin{tabular}{|c|c|c|}
\hline Area & Year & Main documents \\
\hline \multirow[t]{6}{*}{$\begin{array}{l}\text { Domestic production of oilseeds } \\
\text { and oil palm }\end{array}$} & 2017 & $\begin{array}{l}\text { Ministry of Agriculture, annual reports (2013-14/2016-17) })^{(52,57-59)} \text { (price support, } \\
\text { National Mission on Sustainable Agriculture) }\end{array}$ \\
\hline & 2017 & Measures to increase oil palm area and production in India ${ }^{(60)}$ \\
\hline & 2014-2017 & National Mission on Oilseeds and Oil Palm (operational guidelines) ${ }^{(44)}$ \\
\hline & 2013 & Formula for the Pricing of Fresh Fruit Bunches of Oil Palm(61) \\
\hline & & Indian Palm Oil Sustainability Framework ${ }^{(38)}$ \\
\hline & & Principles and criteria for the production of sustainable palm oil( 62$)$ \\
\hline \multirow[t]{4}{*}{ Foreign trade and investment } & 2016 & Consolidated FDI policy (effective from 7 June 2016) \\
\hline & $2012-16$ & $\begin{array}{l}\text { Department of Food and Public Distribution, annual reports }{ }^{(45,64-70)} \text { (policy on } \\
\text { edible oils and commodity monitoring and central scheme for distribution) }\end{array}$ \\
\hline & 2013 & Principles and criteria for the production of sustainable palm oil(62) \\
\hline & $2008-2017$ & $\begin{array}{l}\text { Ban of exports of edible oils, amendments }{ }^{(71)} \text { (amendment notifications: } \\
\text { No. } 03 / 3015-20 \text {, No. } 43 / 2015-20)\end{array}$ \\
\hline \multirow[t]{2}{*}{ Oil processing } & 2016 & Fortification of essential food commodities ${ }^{(72)}$ \\
\hline & 2013 & $\begin{array}{l}\text { Regulation of Trans Fatty Acids (TFA) in Partially Hydrogenated Vegetable Oils } \\
(\text { (PHVO) })^{(43)}\end{array}$ \\
\hline Food processing & 2016 & Ministry of Food Processing Industries annual report $2016-17^{(73)}$ \\
\hline Labelling, advertising & 2011 & Food safety and standards (packaging and labelling) regulations ${ }^{(42)}$ \\
\hline Street food & 2016 & Food Safety and Standards Authority of India annual report $2015-16^{(74)}$ \\
\hline School food environments & 2015 & $\begin{array}{l}\text { Initiative to address the Consumption of Foods High in Fat, Salt and Sugar } \\
\text { (HFSS) and Promotion of Healthy Snacks in Schools of India }{ }^{(55,75)}\end{array}$ \\
\hline Public food distribution & 2013 & National Food Security Act, $2013^{(40)}$ \\
\hline
\end{tabular}

$\mathrm{FDI}$, foreign direct investment.

providing advice to policy makers and government actors, as well as in interpreting policy. Written informed consent was obtained at the time of the interview and permission was sought for recording; this was granted in all but two cases in which detailed notes were taken.

We obtained our initial sample through a purposeful normative approach ${ }^{(26)}$, based on a representation of 'how the system works' ${ }^{\text {(27); }}$; in this case, corresponding to a simplified representation of the edible oils value chain (see online supplementary material). Additional interviewees were identified through snowballing. Interviewees were identified among senior representatives at the level of Director or CEO of the relevant institutions. The academics interviewed were experts with an established reputation, who also acted as policy advisors.

Interviews covered topics related to sectoral context, including perceptions about drivers and trends of oil consumption, the policy process (role and priorities of different state and non-state actors), as well as perceptions around different dimensions of sustainable nutrition, and characteristics of current interventions.

Interviews were transcribed verbatim and manually open coded using a combination of content and thematic analysis $^{(28)}$, based on our theoretical framework ${ }^{(20)}$. Quotes in the text are marked with the following initials: CS (civil society), IN (Industry), S (State), Ac/P (academic expert/policy advisor).

Information obtained from interviews was complemented with the analysis of seventy documents including annual reports, resolutions, notifications and other official policy documents, as well as corporate reports (see Table 2) ${ }^{(29)}$.
Documents were coded using similar themes to those used for interview analysis, also following our theoretical framework.

\section{Policy space analysis}

Table 3 provides an overview of the opportunities and barriers for a sustainable nutrition agenda in the Indian edible oils sector, which are described in additional detail below.

\section{Context}

In this section we describe how broader international and national policy priorities can affect the space for promotion of sustainable healthy oil consumption in India.

Since liberalization of the oil sector in the early 1990s, trade policy has been shaped by participation in the World Trade Organization (WTO). Although the agreements establish high bound tariffs* for palm and other oils (300\%), the scope for effective protection has been limited by the relatively low bound tariff agreed for soyabean ( $45 \%$ ), which is a close substitute. More recently, palm oil bound tariff reductions (to $45 \%$ ) have been negotiated with South-East Asian nations ${ }^{(30)}$. Close relationships with supplying countries, as part of India's 'Look East' (now 'Act East') geopolitical strategy ${ }^{(31)}$, have also played a historical role in the liberalization of palm oil imports, promoted by the Malaysian Palm Oil Council( ${ }^{(32)}$.

*Bound tariffs rates are established as a commitment to WTO. If a country increases tariff rates beyond the bound rate, other WTO countries can demand compensation or retaliate by means of proportional trade policy measures. 
Table 3 Opportunities and barriers for a sustainable nutrition agenda in the Indian edible oils sector

\begin{tabular}{|c|c|c|}
\hline Policy context & Policy process/circumstance & Policy characteristics \\
\hline $\begin{array}{l}\text { Opportunities } \\
\text { - Emergence of multisectoral approaches to } \\
\text { NCD, including explicit goals for reduction } \\
\text { of saturated and trans fats } \\
\text { - Increasing recognition of climate adaptation } \\
\text { as national priority, framing sectoral } \\
\text { interventions as part of broader strategic } \\
\text { plans (National Action Plan for Climate } \\
\text { Change (NAPCC); National Mission on } \\
\text { Sustainable Agriculture (NMSA)) }\end{array}$ & $\begin{array}{l}\text { - Structures for policy coordination at } \\
\text { sectoral level (through former Directorate } \\
\text { of Vanaspati, Vegetable Oils and Fats } \\
\text { (DVVOF)) support policy coherence } \\
\text { - Increased role of health policy actors in the } \\
\text { sector } \\
\text { - Precautionary approach to debate around } \\
\text { health impacts of SFA } \\
\text { - Increased engagement of sustainability- } \\
\text { oriented social actors in the sector (through } \\
\text { corporate actors) } \\
\text { - Potential civil society support for inclusion } \\
\text { of local edible oils in the public distribution } \\
\text { system, shifting away from reliance on } \\
\text { imported palm oil for food security } \\
\text { interventions }\end{array}$ & $\begin{array}{l}\text { - Explicit inclusion of sustainability goals in } \\
\text { current agricultural interventions } \\
\text { - Interventions targeting oilseed } \\
\text { smallholders provide opportunities for the } \\
\text { inclusion of nutrition-sensitive approaches } \\
\text { - Growing number of interventions explicitly } \\
\text { aimed at promoting healthy fats address } \\
\text { edible oil processing, labelling or use in } \\
\text { food processing }\end{array}$ \\
\hline $\begin{array}{l}\text { Barriers } \\
\text { - International agreements increasingly } \\
\text { constrain the trade policy space for oils } \\
\text { - Historical commitment to food security } \\
\text { understood as energy provision and price } \\
\text { stability } \\
\text { - Division of powers across central and State } \\
\text { governments can affect implementation of } \\
\text { key policies }\end{array}$ & $\begin{array}{l}\text { - Pursuit of sustainable nutrition } \\
\text { constrained by broader sectoral priorities: } \\
\text { reduced import dependence, food } \\
\text { security. Protection of domestic producers } \\
\text { (industry) } \\
\text { - Nutrition and sustainability advocates focus } \\
\text { on different segments of the value chain } \\
\text { - Debate over energy focus } v \text {. fatty acid/NCD } \\
\text { focus perceived as a barrier for policy } \\
\text { influence of nutrition advocates }\end{array}$ & $\begin{array}{l}\text { - NCD prevention not explicitly included in } \\
\text { agricultural interventions/policies targeting } \\
\text { the informal sector } \\
\text { - Key policies (e.g. tariff setting, oil } \\
\text { distribution) directly affect economic } \\
\text { interests of organized stakeholders } \\
\text { (domestic producers) or exhibit regional } \\
\text { inequalities in impact, complicating design } \\
\text { and adoption }\end{array}$ \\
\hline
\end{tabular}

NCD, non-communicable disease.

Although liberalization has been partially driven by international geopolitical and economic concerns, the commitment to national food security has played an important role throughout India's participation in trade agreements ${ }^{(33)}$. This priority has been reinforced both nationally, with the approval of the National Food Security Act (2013), and internationally, with the leading role of India in the G33 group of countries, demanding greater flexibilities to defend food security within $\mathrm{WTO}^{(34)}$. Although food security policy has focused mainly on cereals, oils are also considered an essential food commodity and oilseed and oil markets are monitored and managed as such, through policies that control prices and availability.

Both improving diets and sustainability are recognized as policy priorities in India. NCD prevention is increasingly recognized as a national concern, requiring multisectoral coordinated efforts ${ }^{(35)}$, wherein diet is identified as the main risk factor for NCD and reduction in saturated fat consumption is an explicit policy goal ${ }^{(36)}$.

Efforts to improve sustainability in the oilseed sector are framed within the broader National Action Plan for Climate Change, which aims to address India's vulnerability to climate change ${ }^{(37)}$. The recent launch of a national sustainability framework in the palm oil sector follows and aligns with similar policy initiatives in Indonesia and Malaysia ${ }^{(38)}$.
Finally, policy making in all areas needs to be understood in the context of a strong division of powers across central and state governments. We refer in our analysis to priorities, processes and actors operating at the central level that might conflict with those of specific state governments, and implementation and dynamics can vary greatly across states. Importantly, state governments can share responsibilities for funding and implementation, including extending or complementing central government policies or imposing exemptions. In the case of agricultural policy, for example, state governments share responsibility for funding and implementation of policies under the National Mission for Sustainable Agriculture ${ }^{(39)}$. In the case of public distribution, individual States can choose whether to distribute edible oils, either through uptake of central schemes or through specific programmes ${ }^{(40)}$. Regulation for packaging and labelling of edible oils is another example where norms are dictated at a central level but state governments can exempt specific oil products to protect small local producers ${ }^{(41)}$.

\section{Policy process and circumstance}

In this section, we have analysed the key policy processes and priorities in the edible oils sector, as well as the role, influence and priorities of actors, focusing on the barriers and opportunities for the promotion of sustainable, healthy oil consumption. 
Table 4 Key institutions and roles in the Indian edible oils sector

\begin{tabular}{|c|c|}
\hline Actor & Role \\
\hline \multicolumn{2}{|l|}{ State } \\
\hline $\begin{array}{l}\text { Department of Food and Public Distribution; Directorate of } \\
\text { Sugar and Edible Oils (Oil Division) }\end{array}$ & $\begin{array}{l}\text { The promotion of food security is the department's main objective, with } \\
\text { a primary focus on food grains. The Oil Division is responsible for } \\
\text { procurement and market monitoring, implementing relevant policies } \\
\text { and serves a function of coordination to promote coherence across } \\
\text { policies }^{(56)}\end{array}$ \\
\hline $\begin{array}{l}\text { Food Safety and Standards Authority of India (FSSAI). } \\
\text { Autonomous body within the Ministry of Health and Family } \\
\text { Welfare }\end{array}$ & $\begin{array}{l}\text { The main responsibility of FSSAI is the regulation and promotion } \\
\text { of food safety and quality standards. Duties include regulation, } \\
\text { monitoring and awareness raising, and can affect import, } \\
\text { processing, storage and distribution, packaging, labelling and } \\
\text { promotion. Since } 2011 \text {, responsibility for licence, safety and } \\
\text { standard parameters in the edible oils sector was transferred } \\
\text { to FSSAI }\end{array}$ \\
\hline Ministry of Agriculture (Oilseeds Division) & $\begin{array}{l}\text { Design and implementation of agricultural policy interventions } \\
\text { (currently National Mission on Oilseeds and Oil Palm (NMOOP)) }\end{array}$ \\
\hline $\begin{array}{l}\text { Other State actors: Ministry of Food Processing Industries } \\
\text { (MOFPI); Ministry of Commerce and Industry }\end{array}$ & $\begin{array}{l}\text { Other institutions with relevant responsibilities are MOFPI, whose goal } \\
\text { is the promotion of food processing through planning, development, } \\
\text { support and regulation of food industries; and the Ministry of } \\
\text { Commerce and Industry, which establishes the overall direction for } \\
\text { foreign trade policy }\end{array}$ \\
\hline
\end{tabular}

Industry and producers

Edible oil producers (oilseed and oil palm growers, importers, The sector is increasingly concentrated, both vertically and processing firms)

horizontally. Important firms include Adani Wilmar, Ruchi Soya, Godrej Agrovet, Cargill and others

Solvent Extractors Association (SEA)

The SEA is an industry representative body counting over 800 members, and is a co-promoter of the Indian Palm Oil Sustainability Framework (IPOS)

\section{Civil society}

Roundtable on Sustainable Palm Oil (RSPO; multistakeholder, including industry)

RSPO is a non-profit multi-stakeholder platform including industry, NGO and banks of investors. RSPO and associated NGO engage with companies to encourage adoption of corporate social responsibility instruments

Non-governmental organizations (NGO) and advocacy groups Various NGO and advocacy groups are active in the sustainability and (various)

Academic and advisory

Academic institutions and professional associations (various)

nutrition areas, aiming to raise awareness among the public and engage state and industry actors. (e.g. the Sustainable Nutrition Coalition, Right to Food movement, Solidaridad, WWF, Centre for Responsible Business, others)

\section{Main priorities and processes driving policy in the edible} oils sector

Table 4 shows the key institutions with relevant responsibilities in the oils sector.

Since 2011, the Food Safety and Standards Authority of India has been actively involved in the edible oils sector and has enumerated several health-oriented policies and regulations, including compulsory labelling of trans-fatty acids and saturated fat, stricter regulation of health claims and tighter norms for sales of blended oils ${ }^{(41-43)}$. Sustainability in the domestic oilseed and oil palm sector is also increasingly recognized, with an emphasis on water conservation as a crucial element for expansion of domestic production ${ }^{(44)}$.

Policy sources identified reduced import dependence as the main goal for edible oil policy. In addition, policy aims to protect domestic producers, with the oil processing industry being perceived as an influential actor in the sector. Both civil society and industry interviewees referred to this influence as exerted directly, through explicit demands and associated with access.

The sector is increasingly concentrated, both horizontally and vertically. Although the four largest firms are involved in all segments of the value chain from oilseed and oil palm production to import and processing, and remain the most powerful non-state actors in the sector, they are affected by the presence of large national and multinational food processing firms. These companies' demand for oils and sourcing practices can play an important role in shaping incentives in the sector.

A history of intervention in the oils sector has created structures for its monitoring and coordination, operating through the Directorate of Vanaspati, Vegetable Oils and Fats (now Oil Division), which supports policy coherence at a sectoral level. Figure 1 shows some of the main policies in the sector (also shown in Tables 2 and 4), illustrating the coordinated sectoral approach, as well as the interaction 


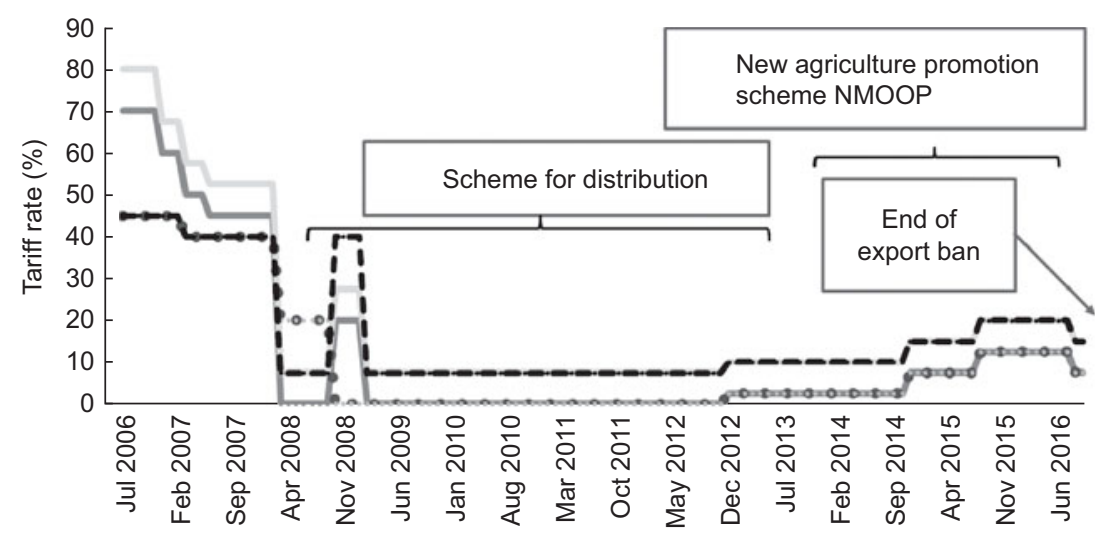

Fig. 1 Some of the main policies in the Indian edible oils sector, 2006-2016: — soyabean oil; - - , refined soyabean oil (NMOOP, National Mission on Oilseeds and Oil Palm)

of competing priorities. Progressive tariff reductions before the international food crisis are reinforced by the introduction of an export ban, and the approval of the scheme for distribution. In the last three years of the decade, progressive increases in tariff rates coincided with the implementation of the agricultural promotion scheme for oilseeds and oil palm (National Mission on Oilseeds and Oil Palm (NMOOP); see Fig. 1).

Despite a certain degree of policy coordination across different areas within the edible oils sector, the relative influence of the priorities described in this section will depend on the specific policy process. We identify three broad processes driving policy intervention in the edible oils sector. First, policy at a sectoral level can be described as an exercise in balancing out key priorities and interests as part of a business-as-usual approach, with policy makers balancing the interests of different stakeholders. One interviewee summarized this approach in the following terms: 'the consumer, [...] the farmers, as well as the industry, we are at the centre, so we have to keep a balance' (P). Second, we identified a crisis approach where narrower interpretations of food security tend to be prioritized. This is the case of edible oil distribution which, unlike grains and sugar, is not covered by the Public Distribution System $(\mathrm{PDS})^{(40)}$. Since the early 1990 s, vegetable oils have only occasionally been distributed to protect consumers from excessive price increases ${ }^{(45,46)}$. The reactive character of this type of policy process was conveyed by an interviewee who commented: 'What happens in India is, the moment the prices peak, the government steps up, imports, through [public] procurement, and then flushes it into the PDS' (CS).

Finally, the pursuit of medium- to long-term strategic goals including self-sufficiency, regional development or water conservation is typically articulated through strategic plans, defining policy goals in a 3- to 5-year period ${ }^{(44)}$, and can alter the business-as-usual balance of priorities. This notion of an overarching strategic priority was conveyed by a former government official, currently heading a civil society organization, who explained:

'We have an initial analysis, [of] whatever we depend on external countries for our requirement. [We] will reduce at least $20-25 \%$ of our requirement by focusing on the edible oil policies [... ]. And so the government sets their own plan for the next five years.' (CS)

Influence of non-state actors on nutrition-related policy Scientific evidence on nutrition regarding edible oils is translated into policy through close contact between regulatory bodies and scientific experts, who regularly take on advisory roles. Awareness and knowledge on NCD prevention among policy makers in key departments can be a supportive factor for translation of nutrition evidence into practice. The interests of industry are taken into account by policy makers, as discussed previously, and interviewees mentioned how producers might attempt to influence implementation and pace of adoption in order to limit economic impacts, potentially applying pressure 'to protect domestic producers by going slow on implementation' (Ac/P). However, interviewees from different areas did not suggest an active role of industry in driving the overall direction of nutrition and health-oriented policy in the edible oils sector, which was considered to be shaped to a larger extent by technical advice.

Nevertheless, there are some challenges for the successful adoption of nutrition-oriented policies in the edible oils sector. The controversy around the health impacts of fatty acid consumption ${ }^{(47,48)}$ is important for the adoption of nutrition-oriented policies for palm oil, with scientific evidence often perceived as being unclear. As one expert put it, following the shift from an emphasis on dietary fats to an emphasis on sugar as a cause for NCD, policy makers are more likely to be sceptical about dietary guidelines, perceiving that 'nutrition has been misleading you all along, for 50 years they have been based on fake science' (Ac/P). However, the nutrition experts 
interviewed generally put emphasis on promoting balanced, culturally appropriate diets.

In the Indian context, the debate seems to focus more on whether to focus on energy intake, or to prioritize the quality of that energy, including balanced fatty acid consumption. Interviewees highlighted this perceived conflict, arguing that 'the main problem with this is that when you say high fat, high sugar, they should be restricted, [...] but that is the kind of food we are serving in the mid-day meal and ICDS [Integrated Child Development Services], because we want to overcome malnutrition' $(\mathrm{Ac} / \mathrm{P})$. This controversy was perceived as problematic, given the increasing divergence in terms of quality of edible oils consumed across socio-economic groups.

One interviewee summarized the debate in the following terms:

'[The] nutrition community itself is fairly divided on this. They would look at the point of view on undernutrition and say that calories are important, and fats can give higher amounts of calories, so why not have fats. The other [approach] [...] the emphasis is shifted to the quality of fats rather than the quantity of fat.' (Ac/P)

Finally, nutrition experts tend to advocate for downstream* policies aimed at processing (regulation of transfatty acids, fortification) or food environments (including packaged food, school food and street food), focusing on advertising, labelling and consumer awareness. Although experts generally supported increased consumption of local oils, upstream policies were considered potentially impractical to deal with urgent concerns, with one expert commenting 'Our agriculture policy has to be reconfigured to have greater production of healthier oils [...] [but] at the moment, we cannot move in that direction' $(\mathrm{Ac} / \mathrm{P})$.

Another interviewee argued for the recent policy focusing on edible oil fortification, referring to the limitations of upstream approaches:

'Ultimately, we have to go for fortification, and that is the only solution that we have. At one of the conferences, a scientist said [to] grow green vegetables at the doorstep, so someone asked where is the door, and where is the step. Because it is very easy to say, but people living in slums, they cannot grow vegetables to eat at doorsteps.' (Ac/P)

Aside from experts and nutrition advocacy coalitions, since 2001 , food security policies have been strongly influenced by a network of civil society organizations and activists campaigning for the recognition of food and nutrition security as an economic and fundamental right ${ }^{(49)}$, as

*We refer here to 'downstream' and 'upstream' as these terms are used in the food systems or value chains literature. The most upstream segments or areas of the value chain include agricultural production and the inputs going into it, while more downstream segments include secondary processing, packaging, distributing, retail and consumption. reflected in the National Food Security Act in 2013. This movement has argued for a broad approach to nutrition security, with a focus on dietary quality, beyond energy intake.

A prominent leader of the campaign and policy adviser commented on the potential support for the inclusion of oils as a regular supply within PDS:

'We had insisted that edible oils should be part of the public distribution system, under the National Food Security Act. That unfortunately has not been the case, and we couldn't incorporate it into the act. But there is a lot of discussion in the government of India, even today, around whether edible oil should be a part of the National Food Security Act.' (CS)

This movement has generally supported local provision and production as part of its approach to nutrition security as a fundamental and economic right, linked to labour and gender rights ${ }^{(49)}$, highlighting upstream approaches as part of an agrarian transformational project.

\section{Influence of non-state actors on sustainability-related policy}

Sustainability concerns have typically been relatively low in the policy agenda for edible oils but are gaining traction partly due to the overall increased urgency around climate adaptation. In particular, the introduction of production methods and seed varieties that reduce water and fertilizer use is considered a priority in order to promote soil and water conservation, and to increase the resilience of oilseed production to droughts ${ }^{(18,39)}$.

In the case of palm oil, the edible oil processing industry has become increasingly interested in sustainability for two main reasons. First, domestic firms have been faced with increased pressure to adopt global sustainability certification schemes, such as the Roundtable on Sustainable Palm Oil (RSPO), to supply multinational food processing firms, which have acquired global commitments for sustainability. Seeing this to a certain extent as a business opportunity but lacking a consumer-based premium for sustainable products, the industry has started to demand policy support and tariff incentives for imports of sustainable oil, so that Indian firms will face 'less duty on green oil, and higher duty on not so green oil' (IN).

One interviewee from industry commented on their proposal to the government:

'[We have proposed that the government should] make the import duties cheaper by 1 or 2 percent so that [we] have more incentive to import sustainable palm oil. If normal duty is $7.5 \% \mathrm{CPO}$, if it is sustainable, you make it $6 \%$.' (IN)

Second, the increased involvement of large processing firms in domestic cultivation of oil palm has also led to growing interest in sustainability initiatives. These 
companies perceive a comparative advantage for cultivation of sustainable palm in India, where it is mainly produced on previously cultivated land, potentially requiring no additional deforestation. In order to realize this perceived competitive advantage, domestic companies have sought policy support for the production of high-value-added sustainable certified products, mainly for the export market, including duty incentives: '[The government should] reduce the export duty for the sustainable palm oil, then once they do it [...] we will request our government to reduce the import duty' (IN).

Civil society actors advocating for sustainability mainly exert their influence through engagement with corporate actors, perceived as the most effective or feasible route given industry incentives and influence. In the case of import policy, potentially conflicting interests were also identified as a barrier for direct engagement with policy and for short-term policy action to promote sustainability.

Civil society actors pointed to the policy inertia created by the historical mandate to protect food security and control prices: 'I don't expect the government of India to implement any kind of regulations [to promote sustainable imports], because their primary concern is to ensure food security' (CS). Only domestic producers, it was perceived, have sufficient influence to overcome this inertia and broaden the agenda for tariff setting.

However, in the context of domestic production, government involvement has been more direct, which was perceived as a positive development, creating an Indian Palm Oil Sustainability Framework (IPOS) ${ }^{(38)}$ focused mainly on domestic production but which also includes oil imports and involves a collaboration among civil society, industry and government.

\section{Policy characteristics}

Relevant characteristics of a policy include not only explicit goals and criteria, but often concern the distribution of costs and impacts across social groups, stakeholders and regions, since these can elicit reactions to policy in social or bureaucratic arenas ${ }^{(22)}$.

\section{Explicit inclusion of nutrition or sustainability criteria}

Table 5 summarizes our results regarding the explicit inclusion of sustainability and nutrition goals within existing policies in the edible oils sector ${ }^{(50)}$.

\section{Distribution of policy impacts and costs}

Although their main aim is not re-distributional, some important interventions in the edible oils sector have a socio-economic impact gradient, disproportionately affecting lower income groups of consumers or producers. This needs to be considered when assessing the space for reform and the potential reactions in social and policy spheres. In particular, state-led agricultural input and production interventions in the oilseed sector directly engage with smallholders, which can potentially
Table 5 Explicit inclusion of nutrition and sustainability criteria in key policies in the Indian edible oils sector

\begin{tabular}{|c|c|}
\hline Area & $\begin{array}{l}\text { Explicit inclusion of sustainable } \\
\text { nutrition goals in current policy }\end{array}$ \\
\hline $\begin{array}{l}\text { Agricultural interventions: } \\
\text { oilseeds and oil palm }\end{array}$ & $\begin{array}{l}\text { - Sustainability explicitly } \\
\text { included (National Mission on } \\
\text { Oilseeds and Oil Palm } \\
\text { (NMOOP)): water and soil } \\
\text { conservation, climate-adapted } \\
\text { varieties }^{(44)} \\
\text { - Nutrition criteria/NCD } \\
\text { prevention not explicitly } \\
\text { included } \\
\text { - Private and public-private } \\
\text { standards have a strong focus } \\
\text { on sustainability and do not } \\
\text { explicitly address issues related } \\
\text { to nutrition/NCD } \\
\text { prevention } \\
(38,62)\end{array}$ \\
\hline International trade & $\begin{array}{l}\text { Sustainability, nutrition/NCD } \\
\text { prevention not explicitly } \\
\text { included } \\
\text { - Food security goals included, } \\
\text { price stability and } \\
\text { availability } 64,68)\end{array}$ \\
\hline $\begin{array}{l}\text { Oil processing, packaging, } \\
\text { labelling and distribution }\end{array}$ & $\begin{array}{l}\text { - Nutrition/NCD prevention } \\
\text { explicitly included in various } \\
\text { policies and regulations }^{(42,43,76)}\end{array}$ \\
\hline $\begin{array}{l}\text { Out-of-home food } \\
\text { environments and use of } \\
\text { edible oils in food } \\
\text { processing }\end{array}$ & $\begin{array}{l}\text { - Nutrition/NCD prevention } \\
\text { explicitly included in various } \\
\text { initiatives targeting the formal } \\
\text { sector } \\
\text { - Initiatives targeting the informal } \\
\text { sector mainly address food } \\
\text { safety }(43,55)\end{array}$ \\
\hline Public distribution & $\begin{array}{l}\text { - Edible oils not included regular } \\
\text { public distribution, and limited } \\
\text { to emergencies, but the } \\
\text { National Food Security Act } \\
\text { explicitly includes a mandate } \\
\text { for improved nutrition through } \\
\text { 'progressive diversification of } \\
\text { commodities distributed under } \\
\text { the Public Distribution System } \\
\text { [... ] ensuring access to } \\
\text { adequate quantity and quality } \\
\text { of food at affordable prices', } \\
\text { potentially supporting the } \\
\text { future inclusion of edible oils } \\
\text { - Sustainability criteria not } \\
\text { explicitly included(40) }\end{array}$ \\
\hline
\end{tabular}

NCD, non-communicable disease.

facilitate the introduction of nutrition-sensitive approaches aimed at vulnerable groups, such as promotion of intercropping, oil crop rotation schemes, provisions for strategic land conversion, farmer training or investment in seed variety improvement ${ }^{(44)}$.

The recent move towards a corporate-led approach in the oil palm component of the NMOOP, however, can shift subsidies and policy focus towards larger producers, while potentially facilitating farmers' access to funding from private investors. With respect to tariff changes or other policies directly affecting prices, palm oil being the cheapest oil in the market, the effects of price increases are most likely to be felt by lower-income households. However, 
palm oil is often consumed in blends or used for food processing, which can reduce consumers' awareness of price fluctuations and the consequent potential for reaction in the social sphere. Distributional impacts are more visible in the case of public distribution, leading to increased civil society engagement, as discussed previously ${ }^{(51)}$.

Perhaps more importantly, key sectoral interventions have marked geographical impact patterns which shape the space for intervention, agricultural interventions and public distribution being the clearest examples. Oil palm development schemes in North-Eastern States, for example, have a strong component of regional development ${ }^{(44)}$. More generally, the costs of NMOOP are shared across central and State governments at a rate of 60:40 (90:10 for North-Eastern States) implying the need for a substantial degree of state-centre coordination ${ }^{(52)}$. The impact of palm oil distribution on producers at a regional level is also important. State governments have sought to protect local producers from the impact of palm oil distribution at subsidized rates ${ }^{(53)}$, leading to unequal geographical adoption of the latest distribution scheme. One policy maker identified this factor, along with reductions in domestic prices, as one of the reasons for irregular adoption of the scheme: 'The different States wanted to distribute different oil. Gujarat wanted to distribute groundnut oil, and Kerala said they wanted to distribute coconut oil instead of palm oil. In 2013 only two states were taking oil, so the Scheme was terminated in September 2013' (P).

Finally, in addition to broader socio-economic or geographical impact patterns, some policies directly impact on the economic interests of key organized stakeholders and, in particular, domestic producers including oil and food processing companies. For example, some interventions targeting food environments, such as compulsory initiatives to promote healthier processed food, can directly affect processing companies, typically requiring a degree of compromise with organized actors in the food industry. This has been the case with the implementation of the ban on trans fats ${ }^{(54)}$ or 'junk food' in schools ${ }^{(55)}$. This is also the case with import tariff changes, whose direct impacts on domestic producers are a key constraining element of the current policy space. In the case of private sustainability standards, the future success of different models is likely to depend on the costs they might impose on large domestic edible oil producers $v$. the advantages provided in terms of access to new markets and contracts with multinational food producers, reflecting the power structure discussed above (section 'Influence of non-state actors on sustainability-related policy').

\section{Discussion and conclusions}

We first discuss opportunities for the promotion of healthier, sustainable edible oils in India, as identified in our study, then discuss the main challenges and conclude with summary observations.

Overall, the implementation of a sectoral agenda for sustainable nutrition is supported by the emergence of multisectoral approaches to NCD prevention ${ }^{(35)}$, as well as by the recognition of climate adaptation as a national priority ${ }^{(39)}$. Moreover, the existence of structures for sectoral policy coordination can support the adoption of coherent, synergistic policies. The increased participation of health actors in the sector has resulted in an increased focus on NCD prevention, with policies addressing oil processing, labelling, distribution and utilization in food processing. Additionally, emergent rights-based civil society movements could provide an important support for the inclusion of local edible oils in the PDS, shifting away from reliance on palm oil for food security interventions. We also find increased engagement from sustainability-oriented civil society actors in the sector, where we see that policy influence is exerted mainly through collaboration with corporate actors in the oil processing industry. Finally, although current agricultural policies in the oilseed sector do not explicitly incorporate goals related to the promotion of healthy oil consumption, the characteristics of these interventions, which directly engage with smallholders, provide opportunities for the adoption of nutritionsensitive approaches.

However, our analysis also identifies some important challenges. The space for trade policy is constrained by international agreements, while overall policy priorities in the edible oils sector are shaped by a history of intervention prioritizing food security. The policy space is also constrained by broader policy priorities including reduced import dependence, price stability, regional development and the protection of domestic producers, and shaped by the alignment of key policies (including tariffs, regulation of processing and 'out of home' environments and public distribution) with the objectives of organized industry stakeholder or individual state government priorities. Furthermore, we find that nutrition and sustainabilityoriented civil society actors tend to focus on different segments within the sector, with sustainability advocates generally addressing upstream issues while nutrition actors tend to focus on downstream segments. Upstream supply-side policies, while viewed positively, are considered impractical as a solution to urgent nutrition-related concerns in the short term. This split might undermine the effectiveness of non-state actors in promoting these sustainable nutrition issues and reduce their ability to leverage the existing structures for sectoral policy coordination. Moreover, the debate between those arguing for a focus on energy from fat and those arguing for a focus on fatty acid quality is perceived as a barrier for the policy influence of nutrition experts in the oils sector. This corroborates previous findings regarding the split policy space for the dual burden of malnutrition in India ${ }^{(6)}$. 
The dynamics surrounding advocacy for sustainability illustrate the changing role of an organized corporate sector. The concerns and strategy of this sector increasingly align with those of global brands, as firms become more consolidated and internationally integrated, becoming active in the corporate social responsibility arena. This represents an important transformation in a sector traditionally dominated by small producers exclusively concerned with domestic or even local markets. Whether in terms of leveraging the corporate sector, or contending with its influence, this is a factor to consider when advocating for policies to promote sustainable, healthier oil consumption, as it is likely to further reshape the policy space.

The present study has some important limitations which should be considered when interpreting our findings. Firstly, we focus on policy at a national level, but many relevant policy processes occur at a state or local level and many of the phenomena discussed, including oilseed and oil palm cultivation, present important regional variation. Second, our focus on policy at a sectoral level limits the level of detail that can be devoted to individual policy processes. More detailed analysis of specific interventions and policy processes at a regional or state level might be the object of further study.

Overall, our analysis highlights important opportunities as well as some challenges for the promotion of sustainable, healthy oil consumption in the edible oils sector in India. The alignment of proposals with broader sectoral priorities including self-sufficiency, food security, the protection of domestic producers and regional development can be important for policy acceptability and successful implementation.

Increased involvement of nutrition advocates with upstream policies in the sector could potentially enhance coherence across policy goals relating to sustainability, energy sufficiency and NCD prevention, addressing perceived trade-offs which have been identified as a barrier for intervention. Systematic efforts towards identifying synergistic approaches, from agricultural production to distribution of edible oils, could also increase policy influence for advocates of both sustainability and nutrition.

\section{Acknowledgements}

Acknowledgements: The authors would like to acknowledge the insightful comments from two anonymous reviewers and from the editors. Financial support: This research was funded by a grant from the Wellcome Trust (grant number 103905/Z/14/Z) under its 'Our Planet, Our Health' initiative. The Wellcome Trust had no role in the design, analysis or writing of this article. Conflict of interest: The authors do not report any conflict of interest. Authorship: S.C., B.S. and S.M.D. contributed to formulating the research question and designing the study, all authors contributed to carrying out the study, S.C. wrote the article and all authors contributed to reviewing the final version. Ethics of human subject participation: This study was conducted according to the guidelines laid down in the Declaration of Helsinki and all procedures involving human subjects were approved by the London School of Hygiene and Tropical Medicine ethics committee and by the Institutional Ethics Committee of the Public Health Foundation of India. Written informed consent was obtained from all subjects.

\section{Supplementary material}

To view supplementary material for this article, please visit https://doi.org/10.1017/S1368980019001836

\section{References}

1. Popkin BM (2003) The nutrition transition in the developing world. Dev Policy Rev 21, 581-597.

2. Popkin BM (2006) Technology, transport, globalization and the nutrition transition food policy. Food Policy 31, 554-569.

3. Misra A, Singhal N, Sivakumar B et al. (2011) Nutrition transition in India: secular trends in dietary intake and their relationship to diet-related non-communicable diseases. J Diabetes 3, 278-292.

4. Vepa SS (2004) Impact of globalization on the food consumption of urban India. In Globalization of Food Systems in Developing Countries: Impact on Food Security and Nutrition. FAO Food and Nutrition Paper no. 83, pp. 215-230. Rome: FAO.

5. Meenakshi J (2016) Trends and patterns in the triple burden of malnutrition in India. Agric Econ 47, 115-134.

6. Thow AM, Kadiyala S, Khandelwal S et al. (2016) Toward food policy for the dual burden of malnutrition: an exploratory policy space analysis in India. Food Nutr Bull 37, 261-274.

7. US Department of Agriculture (2016) Production, Supply \& Distribution database. https://apps.fas.usda.gov/psdonline/ app/index.html\#/app/home (accessed July 2019).

8. Downs SM, Thow AM, Ghosh-Jerath S et al. (2014) Aligning food-processing policies to promote healthier fat consumption in India. Health Promot Int 30, 595-605.

9. Shankar B \& Hawkes C (2013) India has a problem with palm oil: a substantial tax could be part of the solution. BMJ $\mathbf{3 4 7}$, f6065.

10. Basu S, Babiarz KS, Ebrahim S et al. (2013) Palm oil taxes and cardiovascular disease mortality in India: economicepidemiologic model. BMJ 347, f6048.

11. Mensink RP, Zock PL, Kester AD et al. (2003) Effects of dietary fatty acids and carbohydrates on the ratio of serum total to HDL cholesterol and on serum lipids and apolipoproteins: a meta-analysis of 60 controlled trials. Am J Clin Nutr 77, 1146-1155.

12. Micha R \& Mozaffarian D (2010) Saturated fat and cardiometabolic risk factors, coronary heart disease, stroke, and diabetes: a fresh look at the evidence. Lipids 45, 893-905.

13. Sun Y, Neelakantan N, Wu Y et al. (2015) Palm oil consumption increases LDL cholesterol compared with vegetable oils low in saturated fat in a meta-analysis of clinical trials. J Nutr 145, 1549-1558.

14. Agus F, Gunarso P, Sahardjo BH et al. (2013) Historical $\mathrm{CO}_{2}$ Emissions from Land Use and Land Use Change from the 
Oil Palm Industry in Indonesia, Malaysia and Papua New Guinea. Kuala Lumpur: Roundtable on Sustainable Palm Oil.

15. Schleifer P (2016) Private governance undermined: India and the roundtable on sustainable palm oil. Glob Environ Polit 16, 38-58.

16. Centre for Responsible Business (2014) Responsible practices in the Indian Palm Oil Sector. https://www.isealalliance.org/ sites/default/files/resource/2018-06/Responsible-BusinessPractices-in-the-Indian-Palm-Oil-Sector-CRB-Feb-2014-PDF. pdf (accessed July 2019).

17. Downs SM, Thow AM, Ghosh-Jerath S et al. (2015) Identifying the barriers and opportunities for enhanced coherence between agriculture and public health policies: improving the fat supply in India. Ecol Food Nutr 54, 603-624.

18. Jha G, Suresh P, Mathur VC et al. (2012) Edible Oilseeds Supply and Demand Scenario in India: Implications for Policy. New Delhi: Indian Agricultural Research Institute.

19. Mall R, Singh R, Gupta A et al. (2006) Impact of climate change on Indian agriculture: a review. Clim Change 78, 445-478.

20. Shankar B, Thaiprasert N, Gheewala S et al. (2017) Policies for healthy and sustainable edible oil consumption: a stakeholder analysis for Thailand. Public Health Nutr 20, 1126-1134

21. Grindle M \& Thomas J (1991) Public Choices and Policy Change: The Political Economy of Reform in Developing Countries. Baltimore, MD: Johns Hopkins University Press.

22. Nordlinger E (1987) Taking the state seriously. In Understanding Political Development, pp. 353-390 [M Weiner and SP Huntington, editors]. Boston, MA: Little Brown.

23. Henson S (2008) The role of public and private standards in regulating international food markets. J Int Agric Trade Dev 4, 63-81.

24. Malterud K, Siersma VD \& Guassora AD (2016) Sample size in qualitative interview studies: guided by information power. Qual Health Res 26, 1753-1760.

25. Heasman M \& Lang T (2015) Food Wars: The Global Battle for Mouths, Minds and Markets. Abingdon: Routledge.

26. Marshall MN (1996) Sampling for qualitative research. Fam Pract 13, 522-526.

27. Hare M \& Pahl-Wostl C (2002) Stakeholder categorisation in participatory integrated assessment processes. Integr Assess 3, 50-62.

28. Ritchie J \& Spencer L (2002) Qualitative data analysis for applied policy research. Qual Res Companion 573, 305-329.

29. Bowen GA (2009) Document analysis as a qualitative research method. Qual Res J 9, 27-40.

30. Francis S (2011) The ASEAN-India free trade agreement: a sectoral impact analysis of increased trade integration in goods. Econ Polit Wkly 46, 46-55.

31. Singh S (2015) India's approach towards bilateral, regional and multilateral negotiations. CUTS International Development Paper. http://www.cuts-citee.org/pdf/Indias_Approach_ towards_Bilateral_Regional_and_Multilateral_Negotiations.pdf (accessed June 2019).

32. Rasiah R (2006) Explaining Malaysia's export expansion in palm oil and related products. In Technology, Adaptation, and Exports: How Some Developing Countries Got It Right, pp. 163-192 [V Chandra, editor]. Washington, DC: International Bank for Reconstruction and Development/ World Bank.

33. Chang H-J (2009) Rethinking public policy in agriculture: lessons from history, distant and recent. J Peasant Stud $\mathbf{3 6}$, $477-515$.

34. Grant JH (2009) Triggers, remedies, and tariff cuts: assessing the impact of a special safeguard mechanism for developing countries. Estey Centre J Int Law Trade Policy 10, 223.

35. Ministry of Health and Family Welfare, Government of India \& World Health Organization (2016) Inter-ministerial
Consultation on National Multisectoral Action Plan for Prevention and Control of NCDs in India. http://www. searo.who.int/india/mediacentre/events/2016/Inter_minis terial_Consultation_on_National_Multisectoral_Action/en/ (accessed July 2019).

36. Bachani D (2017) National Multi-sectoral Action Plan for Prevention \& Control of NCDs in India. Webinar on 'Double-Duty' Policies for Improved Nutrition. https:// www.spring-nutrition.org/sites/default/files/events/files/ spring_june7webinar_bachani.pdf (accessed July 2019).

37. Government of India, Prime Minister's Council on Climate Change (2008) National Action Plan on Climate Change. New Delhi: Government of India, Prime Minister's Council on Climate Change.

38. Solidaridad (2017) India adopts national framework for sustainable palm oil production. https://www.solidaridadnetwork. org/news/india-adopts-national-framework-for-sustainablepalm-oil-production (accessed July 2019).

39. Department of Agriculture and Cooperation, Ministry of Agriculture and Farmers Welfare, Government of India (2014) National mission for sustainable agriculture operational guidelines. https://nmsa.dac.gov.in/ (accessed July 2019).

40. Ministry of Law and Justice, Government of India (2013) The National Food Security Act. http://egazette.nic.in/ writereaddata/2013/e_29_2013_429.pdf (accessed July 2019).

41. Food Safety and Standards Authority of India, Ministry of Health and Family Welfare, Government of India (2011) Food safety and standards prohibition and restriction on sales regulation 2011 and FAQ. http://www.fssai.gov.in/home/ compliance/regulations/prohibition-and-restrictions-onsales.html (accessed July 2019).

42. Food Safety and Standards Authority of India, Ministry of Health and Family Welfare, Government of India (2011) Food Safety and Standards (Packaging and Labelling) Regulation, 2011. https://archive.fssai.gov.in/home/fsslegislation/fss-regulations.html (accessed July 2019).

43. Food Safety and Standards Authority of India, Ministry of Health and Family Welfare, Government of India (2013) Food Safety and Standards (Packaging and Labelling) Second Amendment Regulations (relating to transfatty acids). https://fssai.gov.in/notifications.php?notification=gazettenotification\&pages $=8$ (accessed July 2019).

44. Ministry of Agriculture and Farmers Welfare, Government of India (2014) National mission on oilseeds and oil palm, operational guidelines. http://nmoop.gov.in/Guidelines/ NMOOP20114.pdf (accessed July 2019).

45. Department of Food and Public Distribution, Ministry of Consumer Affairs, Food and Public Distribution, Government of India (2013) Annual Report 2012-13. http://dfpd.nic.in/ annual-report.htm (accessed July 2019).

46. Food and Agriculture Organization of the United Nations (1993) Public distribution system in India - evolution, efficacy and need for reforms. http://www.fao.org/docrep/ $\mathrm{x} 0172 \mathrm{e} / \mathrm{x} 0172 \mathrm{e} 06 . \mathrm{htm}$ (accessed July 2019).

47. Mozaffarian D (2011) The great fat debate: taking the focus off of saturated fat. J Am Diet Assoc 111, 665-666.

48. Wang DD, Li Y, Chiuve SE, et al. (2016) Association of specific dietary fats with total and cause-specific mortality. JAMA Intern Med 176, 1134-1145.

49. Hertel S (2015) Hungry for justice: social mobilization on the right to food in India. Dev Change 46, 72-94.

50. Swanson KS, Carter RA, Yount TP et al. (2013) Nutritional sustainability of pet foods. Adv Nutr 4, 141-150.

51. Pande S \& Houtzager P (2016) Civil Society Innovation and Resilience in the Struggle for the Right to Food in India. Brighton: Institute of Development Studies, University of Sussex.

52. Ministry of Agriculture and Farmers Welfare, Government of India (2016) Annual Report 2015-16. http://agricoop.nic.in/ annual-report (accessed July 2019). 
53. Commission for Agricultural Costs and Prices, Department for Cooperation and Agriculture and Farmers Welfare, Ministry of Agriculture, Government of India (2012) Price Policy for Copra. The 2013 season. https://cacp.dacnet. nic.in/ViewReports.aspx?Input $=2 \&$ PageId $=37 \&$ KeyId $=528$ (accessed July 2019).

54. Downs SM, Gupta V, Ghosh-Jerath S et al. (2013) Reformulating partially hydrogenated vegetable oils to maximise health gains in India: is it feasible and will it meet consumer demand? BMC Public Health 13, 1139.

55. HFSS Working Group, Ministry of Women and Child Development, Government of India (2015) Report of Working Group on Addressing Consumption of Foods High in Fat, Salt and Sugar (HFSS) and Promotion of Healthy Snacks in Schools of India. http://www.indiaenvironment portal.org.in/content/421707/report-of-working-group-onaddressing-consumption-of-foods-high-in-fat-salt-and-sugarhfss-and-promotion-of-healthy-snacks-in-schools-of-india/ (accessed July 2019).

56. Sutton R (1999) The Policy Process: An Overview. London: Overseas Development Institute.

57. Ministry of Agriculture and Farmers Welfare, Government of India (2014) Annual Report 2013-14. http://agricoop.nic.in/ annual-report (accessed July 2019).

58. Ministry of Agriculture and Farmers Welfare, Government of India (2015) Annual Report 2014-15. http://agricoop.nic.in/ annual-report (accessed July 2019).

59. Ministry of Agriculture and Farmers Welfare, Government of India (2017) Annual Report 2016-17. http://agricoop.nic.in/ annual-report (accessed July 2019).

60. Press Information Bureau, Government of India (2017) Cabinet approves measures to increase oil palm area and production in India. http://pib.nic.in/newsite/PrintRelease. aspx?relid=160970 (accessed July 2019).

61. Ministry of Agriculture and Farmers Welfare, Government of India (2013) Formula for the pricing of Fresh Fruit Bunches of Oil Palm. http://agricoop.nic.in/sites/default/files/ FormulapricingFFBs_0.pdf (accessed July 2019).

62. Roundtable on Sustainable Palm Oil (2013) Principles and Criteria for the Production of Sustainable Palm Oil. https:// rspo.org/resources/archive/77 (accessed July 2019).

63. Department of Industrial Policy and Promotion, Ministry of Commerce and Industry, Government of India (2016) Consolidated FDI policy. http://dipp.nic.in/foreign-direct-investment/ foreign-direct-investment-policy (accessed July 2019).

64. Department of Food and Public Distribution, Ministry of Consumer Affairs, Food and Public Distribution, Government of India (2009) Annual Report 2008-09. http://dfpd.nic.in/ annual-report.htm (accessed July 2019).

65. Department of Food and Public Distribution, Ministry of Consumer Affairs, Food and Public Distribution, Government of India (2010) Annual Report 2009-10. http://dfpd.nic.in/ annual-report.htm (accessed July 2019).

66. Department of Food and Public Distribution, Ministry of Consumer Affairs, Food and Public Distribution, Government of India (2011) Annual Report 2010-11. http://dfpd.nic.in/ annual-report.htm (accessed July 2019).

67. Department of Food and Public Distribution, Ministry of Consumer Affairs, Food and Public Distribution, Government of India (2012) Annual Report 2011-12. http://dfpd.nic.in/ annual-report.htm (accessed July 2019).

68. Department of Food and Public Distribution, Ministry of Consumer Affairs, Food and Public Distribution, Government of India (2014) Annual Report 2013-14. http://dfpd.nic.in/ annual-report.htm (accessed July 2019).

69. Department of Food and Public Distribution, Ministry of Consumer Affairs, Food and Public Distribution, Government of India (2015) Annual Report 2014-15.http:// dfpd.nic.in/annual-report.htm (accessed July 2019).

70. Department of Food and Public Distribution, Ministry of Consumer Affairs, Food and Public Distribution, Government of India (2016) Annual Report 2015-16. http://dfpd.nic.in/ annual-report.htm (accessed July 2019).

71. Director General of Foreign Trade, Government of India (2008) Notification NO. 85/2007, DT. 17/03/2008 Ban on export of Edible Oils (Chapter 15). http://www.eximkey. $\mathrm{com} /$ notification.php?intId=4120\&Path=/Sec/DGFT/Notific ationCirculars/Notifications/NotificationsIssuedYr07/NOTI FICATION_NO_85-2007_DT_17-03-2008.htm (accessed July 2019).

72. Food Safety and Standards Authority of India, Ministry of Health and Family Welfare, Government of India (2016) Fortification of Foods Regulation 2016. https://fssai.gov.in/search.php? $\mathrm{cx}=009166207481149357514 \% 3$ Anohrtd59j_a\&cof=FORID\% 3A10\&ie $=\mathrm{UTF}-8 \& \mathrm{q}=$ fortification (accessed July 2019).

73. Ministry of Food Processing Industries, Government of India (2017) Ministry of Food Processing Industries annual report, 2016-17. http://www.mofpi.nic.in/documents/ reports/annual-report (accessed July 2019).

74. Food Safety and Standards Authority of India, Ministry of Health and Family Welfare, Government of India (2016) FSSAI Annual Report 2015/16. https://archive.fssai.gov.in/ home/FSSAI-Annual-Reports.html (accessed July 2019).

75. HFSS Working Group, Ministry of Women and Child Development, Government of India (2014) Junk Food Guidelines Draft. Working Group set up by the Expert Group set up as per the order dated September 4, 2013 of the Honorable High Court of Delhi on guidelines for making available quality and safe food in schools. http://www. indiaenvironmentportal.org.in/content/390598/draft-guide lines-for-regulating-food-high-in-fat-sugar-and-salt-hfss-alsopopularly-known-as-junk-food/pdf (accessed July 2019).

76. Food Safety and Standards Authority of India, Ministry of Health and Family Welfare, Government of India (2011) Food Safety and Standards (Prohibition and Restrictions on Sales Regulations 2011). http://fsdaup.gov.in/writereaddata/ images/pdf/act-and-rules/fss-regulation/Food-safety-andstandards-Prohibition-and-Restrction-on-sales-regulation2011.pdf (accessed July 2019). 